\title{
Prevalence and Molecular Diagnosis of Escherichia coli in captive Sloth Bears (Melursus ursinus)
}

\author{
M. Palanivelrajan ${ }^{1 *}$, A. Sha Arun ${ }^{2}$, M.G. Jayathangaraj ${ }^{3}$, K. Vijayarani ${ }^{4}$, \\ Bhaskaran Ravi Latha ${ }^{5}$, P. Sridevi ${ }^{6}$ and K. Porteen ${ }^{7}$
}

\author{
${ }^{1}$ Department of Wildlife Science, ${ }^{3}$ Department of Veterinary Clinical Medicine, \\ ${ }^{4}$ Department of Animal Biotechnology, ${ }^{5}$ Department of Veterinary Parasitology, \\ ${ }^{6}$ Department of Clinics, ${ }^{7}$ Department of Veterinary Public Health and Epidemiology, Madras \\ Veterinary College, Tamil Nadu Veterinary and Animal Sciences University, Chennai, \\ Tamil Nadu-600 007 India \\ ${ }^{2}$ Research \& Veterinary Operations, Wildlife SOS, Bannerghatta Bear Rescue Centre, \\ Bannerghatta Biological Park, Bangalore - 560083 Karnataka, India
}

*Corresponding author

\section{A B S T R A C T}

Pathogenic Escherichia coli strain from faeces of sloth bears was screened by using culture morphology, Gram's staining, biochemical tests and polymerase chain

Keywords

Antibiogram,

Escherichia coli,

fim $\mathrm{C}$ gene, Sloth

Bear, Ursidae

Article Info

Accepted:

04 September 2018

Available Online:

10 October 2018 reaction. Our results showed that out of 60 samples collected, 59 samples (98.33\%) were cultured on EMB agar and Gram's stain revealed rod-shaped Gram-negative organism with green metallic sheen - like colonies. The biochemical tests of cultured samples revealed positive to indole production, positive to methyl red test, negative to Voges-Proskauer test, negative to Simmon citrate utilization test, positive to glucose, negative to $\mathrm{H}_{2} \mathrm{~S}$ production and negative to urea production. All E. coli isolates were found sensitive to azithromycin, streptomycin and tetracycline. They were found intermediate to enrofloxacin and gentamicin. The fim $C$ gene was amplified by PCR for the pathogenic Escherichia coli and were found to be positive of 53.33\% among the juveniles, $46.67 \%$ among the sub-adults, 53.33\% among the adults and $33.33 \%$ among the geriatrics were found to be positive. This study may provide information for developing strategies in the future in the control of Escherichia coli infections in sloth bears.

\section{Introduction}

Ursidae have a complex gut microbiota resulting from a dynamic interplay among diet, host and commensal bacteria, which play an important role in the maintenance of health and disease modulation. The composition of the gut microbiota depends on the physiology of the gut as well as the type of diet and varies among the hosts (Ley et al., 2008). Ursids 
including Sloth Bear (Melursus ursinus) are an enigmatic family. Escherichia coli are part of the normal intestinal microbiota and coexist with its host in mutual benefit. Captive animals, especially those acquired from the wild can be asymptomatic carriers of pathogens. Some of these pathogens have also caused morbidity and mortality in animals within zoological gardens. Escherichia coli are often a long-term commensal in animals, a part of their normal intestinal microbial community. Escherichia coli can cause a variety of diseases including dysentery, haemorrhagic uremia syndrome, bladder and kidney infections, septicemia, pneumonia, and meningitis in humans and animals (Cambre et al., 1980). The intestinal microbiota can also be a reservoir of extra intestinal pathogenic Escherichia coli and strains from the intestinal microbiota of the Sloth Bear are scanty. The aim of this study was to investigate and characterize faecal Escherichia coli from sloth bear (Melursus ursinus).

\section{Materials and Methods}

In this study, fecal samples were collected from Bannerghatta Bear Rescue Centre (BBRC), Wildlife SOS, Bangalore, Karnataka. During the sampling period in 2017, the faecal samples from 15 juvenile, 15 sub-adult, 15 adult and 15 geriatric captive sloth bears were collected in nutrient broth using sterile swabs and kept at $4^{0} \mathrm{C}$ until further processing. The swabs were incubated at $37^{\circ} \mathrm{C}$ for $24 \mathrm{hrs}$. A loop-full of culture was then spread on Nutrient Agar plate and incubated further at $37^{\circ} \mathrm{C}$ for $24 \mathrm{hrs}$. Eosin Methylene Blue (EMB) media was used as a selective and differential culture media. A loop-full of culture was spread on Eosin Methylene Blue (EMB) agar and incubated at $37^{\circ} \mathrm{C}$ for $24 \mathrm{hrs}$ to obtain of Escherichia coli colonies. The isolated colony was stained with Gram's stain and biochemical tests (HiIMViC ${ }^{\mathrm{TM}}$ Biochemical Test Kit, TSI agar and urea agar) and was confirmed by Polymerase Chain Reaction (PCR).

Antimicrobial resistance pattern of pathogen E. coli isolates were studied by Modified Kirby-Bauer disc diffusion method according to Clinical and Laboratory Standards Institute (CLSI) guidelines (CLSI, 2006) for the following antibiotics: amoxicillin/clavulanic acid (30mcg), azithromycin (15mcg), cefotaxime (30 mcg), clindamycin ( $2 \mathrm{mcg}$ ), gentamicin $(10 \mathrm{mcg})$, enrofloxacin $(10 \mathrm{mcg})$, methicillin $(5 \mathrm{mcg})$, streptomycin $(300 \mathrm{mcg})$ and tetracyline $(30 \mathrm{mcg})$.

For the PCR reaction, the DNA was extracted from the isolates by using boiling method (Medici et al., 2003). One $\mathrm{ml}$ of the preenriched culture was transferred to a $1.5 \mathrm{ml}$ micro-centrifuge tube. The cell suspension was centrifuged for $10 \mathrm{~min}$ at $10,000 \mathrm{rpm}$. The supernatant was discarded carefully. The pellet was resuspended in $300 \mu 1$ of DNaseRNase- free water by vortexing. The tube was centrifuged at $10,000 \mathrm{rpm}$ for $5 \mathrm{~min}$, and the supernatant was discarded carefully. The pellet was resuspended in $200 \mu$ l of DNaseRNase-free water by vortexing. The microcentrifuge tube was incubated for $15 \mathrm{~min}$ at $100^{\circ} \mathrm{C}$ and immediately chilled on ice. The tube was centrifuged for $5 \mathrm{~min}$ at $10,000 \mathrm{rpm}$ at $4^{\circ} \mathrm{C}$. The supernatant was carefully transferred to a new microcentrifuge tube and incubated again for $10 \mathrm{~min}$ at $100^{\circ} \mathrm{C}$ and chilled immediately on ice. Further, it as stored at $-20^{\circ} \mathrm{C}$. An aliquot of $5 \mu \mathrm{l}$ of the supernatant was used as template in the PCR. The molecular weight of the fimC gene corresponding to the avian pathogenic Escherichia coli was 477bp (Janben et al., 2001). The following primers were used to amplify the fimC gene (Forward Primer: 5'GGGTAGAAAATGCCGATGGTG-3' and Reverse Primer: 5'-CGTCATTTTGGG GGTAAGTGC-3'). The PCR was performed in a $25 \mu 1$ reaction mixture consisting of $12.5 \mu 1$ 
of 2 X PCR mastermix, $1 \mu 1$ of each primer, $2 \mu 1$ of extracted DNA and finally volume was adjusted with nuclease free water. Amplification was carried out in thermocycler with initial denaturation $94^{\circ} \mathrm{C}$ for $2 \mathrm{~min}$ followed by 25 cycles each of denaturation at $94^{\circ} \mathrm{C}$ for $1 \mathrm{~min}$, annealing at $59^{\circ} \mathrm{C}$ for $1 \mathrm{~min}$, extension at $92^{\circ} \mathrm{C}$ for $90 \mathrm{sec}$ with a final extension period of $7 \mathrm{~min}$ at $72^{\circ} \mathrm{C}$. $10 \mu \mathrm{l}$ of each PCR products was electrophoresed on $1.5 \%$ agrose gel containing ethidium bromide in the presence of $100 \mathrm{bp}$ ladder. The presence specific amplicon of $477 \mathrm{bp}$ was viewed under UV transilluminator.

The PCR amplifies the fim $\mathrm{C}$ gene of the one of the isolate was sequenced using commercial sequencing service.

\section{Results and Discussion}

Out of 60 samples collected, 59 samples (98.33\%) were cultured on EMB agar and green metallic sheen - like colonies (Figure 1) were picked for Gram's staining and revealed Gram-negative rod-shaped organism.

Usage of biochemical tests in $\mathrm{HiIMViC}^{\mathrm{TM}}$ Biochemical Test Kit, TSI agar and urea agar revealed that were positive to indole production, positive to methyl red test, negative to Voges-Proskauer test, negative to
Simmon citrate utilization test, positive to glucose, negative to $\mathrm{H} 2 \mathrm{~S}$ production and negative to urea production in cultured samples. All E. coli isolates which were studied have been found sensitive to azithromycin, streptomycin and tetracycline.

They were found intermediate to enrofloxacin and gentamicin.

Further, based on the PCR assay, among $53.33 \%$ juvenile, $46.67 \%$ sub-adult, $53.33 \%$ adult and $33.33 \%$ geriatric screened for the pathogenic Escherichia coli were found positive. In the juvenile sloth bear group, three males and five females harboured the infection (60.00 and $50.00 \%$, respectively), in the subadult group, four males and three females harboured the infection $(66.67 \%$ and $33.33 \%$, respectively), in the adult group one male and seven females harboured the infection (20.00\% and $70.00 \%$, respectively) and in the geriatric group three male and two females harboured the infection $(27.27 \%$ and $50.00 \%$, respectively) (Figure 2 and Table 1).

The fim $\mathrm{C}$ gene was chosen for amplification since presence of this gene indicates the $E$. coli as a pathogenic gene. All the isolates from the sloth bears were positive for the presence of fim $\mathrm{C}$ gene indicating the pathogenic nature.

Fig.1 Escherichia coli on Eosin Methylene Blue (EMB) Agar

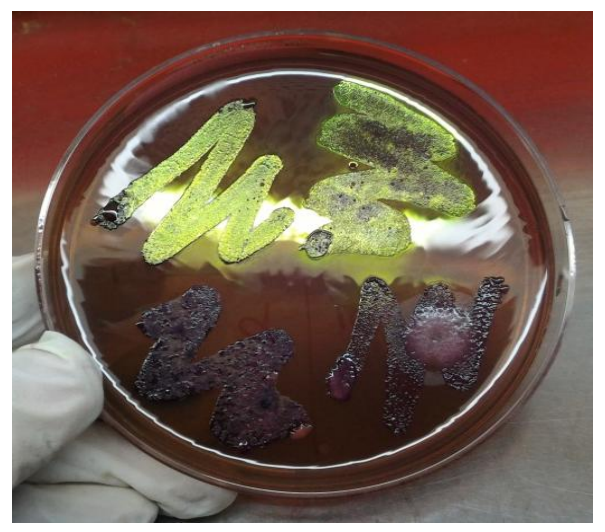


Fig.2 Amplification of Escherichia coli by PCR

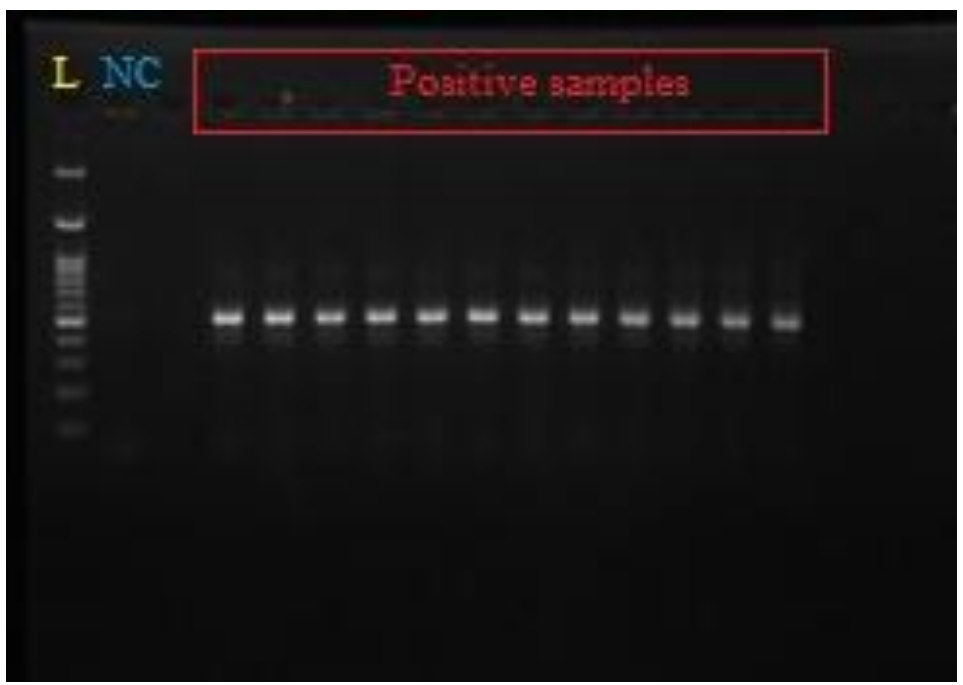

$1.5 \%$ agarsoe showing PCR products of fimC gene

Lane L - DNA ladder (500bp)

Lane NC - Negative control

Lane postitive samples - fimC gene amplification (477bp)

Supplement: Partial nucleotide sequence of fim $\mathrm{C}$ gene from E. coli isolated from sloth bear (Melursus ursinus)

>ConsensusTTTGGGTAGAAAAATGCCGATGGTGTAAAGGATGRKCGKTTTATCGTGA CGCCTCCTCTGTTTGCGATGAAGGGAAAAAAAGAGAATACCTTACGTATTCTTGATG CAACAAATAACCAATTGCCACAGGATCGGGAAAGTTTATTCTGGATGAACGTTAAA GCGATTCCGTCAATGGATAAATCAAAATTGACTGAGAATACGCTACAGCTCGCAATT ATCAGCCGCATTAAACTGTACTATCGCCCGGCTAAATTAGCGTTGCCACCCGATCAG GCCGCAGAAAAATTAAGATTTCGTCGTAGCGCGAATTCTCTGACKCTGATTAACCCG ACACCCTATTACCTGACGGTAACAGAGTTGAATGCCGGAACCCGGGTTCTTGAAAAT GCATTGGTGCCTCCAATGGGCGAAAGCACGGTTAAATTGCCTTCTGATGCAGGAAGC AATATTACYTWCCGAACAMTAAATGATTATGGCGCACTTACCCCCAAAATGACGAA

\begin{tabular}{|c|c|}
\hline IUPAC nucleotide code & Base \\
\hline A & Adenine \\
\hline C & Cytosine \\
\hline G & Guanine \\
\hline T (or U) & Thymine (or Uracil) \\
\hline R & A or G \\
\hline Y & C or T \\
\hline W & A or T \\
\hline K & G or T \\
\hline M & A or C \\
\hline
\end{tabular}


Table.1 Prevalence of Escherichia coli in Sloth Bears (Melursus ursinus) by PCR

\begin{tabular}{|c|c|c|c|c|}
\hline $\begin{array}{l}\text { Group of animals } \\
\qquad(\mathrm{n}=30)\end{array}$ & Sex & Samples collected & $\begin{array}{c}\text { Positive for pathogenic } \\
\text { Escherichia coli }\end{array}$ & $\begin{array}{c}\text { Prevalence } \\
(\%)\end{array}$ \\
\hline \multirow{3}{*}{$\begin{array}{c}\text { Juvenile } \\
(2-7 \text { years }) \\
(n=15)\end{array}$} & Male & 5 & 3 & 60.00 \\
\hline & Female & 10 & 5 & 50.00 \\
\hline & Both & 15 & 8 & 53.33 \\
\hline \multirow{3}{*}{$\begin{array}{l}\text { Sub-adult } \\
(8-13 \text { years }) \\
(n=15)\end{array}$} & Male & 6 & 4 & 66.67 \\
\hline & Female & 9 & 3 & 33.33 \\
\hline & Both & 15 & 7 & 46.67 \\
\hline \multirow{3}{*}{$\begin{array}{c}\text { Adult } \\
(14-18 \text { years }) \\
(n=15)\end{array}$} & Male & 5 & 1 & 20.00 \\
\hline & Female & 10 & 7 & 70.00 \\
\hline & Both & 15 & 8 & 53.33 \\
\hline \multirow{3}{*}{$\begin{array}{c}\text { Geriatric } \\
\text { (above } 19 \text { years) } \\
(n=15)\end{array}$} & Male & 11 & 3 & 27.27 \\
\hline & Female & 4 & 2 & 50.00 \\
\hline & Both & 15 & 5 & 33.33 \\
\hline
\end{tabular}

The sequence results were compared with that of the pathogenic E. coli isolate sequences using nBLAST (Nucleotide local alignment service tool) available at https://blast.ncbi.nlm.nih.gov/Blast.cgi?PAGE _TYPE=BlastSearch. The sequence data is provided as supplement.

The prevalence of $46.67 \%$ of pathogenic Escherichia coli confirms the presence of infection and ampleness of the bacteria in the Bannerghatta Bear Rescue Centre (BBRC). The isolated pathogenic Escherichia coli which could be either enteropathogenic, enterohaemorrhagic or commensal are the possible cause of zoonotic infection in wild animals and in humans. The sources of infection could not be revealed. The possible sources could be food, water, birds, visitors, rodents, lizards and bats (Oludairo et al., 2016). The sloth bear are omnivores animal and has yield a $46.67 \%$ rate of pathogenic Escherichia coli infection and which is in agreement with the findings of Gopee et al., (2000) who reported isolation of Escherichia coli from omnivores, herbivores, and carnivores at the rate of $87.2 \%, 70.0 \%$, and $57.3 \%$, respectively, regardless of animal class, were significantly different. Most (99.6\%) of the Escherichia coli isolates tested for antibiotic sensitivity exhibit resistance to one or more of the antimicrobial agents used. Resistance was generally high to cephalothin (99.2\%), ampicillin (62.4\%), tetracycline $(58.2 \%)$, and streptomycin $(36.0 \%)$ but low to gentamicin $(9.6 \%)$, chloramphenicol $(1.6 \%)$, and norfloxacin $(0.4 \%)$. Captive wildlife in zoo enclosures is potentially exposed to strains of Escherichia coli through contact with animal handlers or through the microorganism in their diets.

\section{Acknowledgement}

The authors are thankful to the Dean, Faculty of Basic Sciences, Tamil Nadu Veterinary and Animal Sciences University, Madras Veterinary College Campus, Chennai and the Founder, Wildlife SoS, Bannerghatta Bear Rescue Centre (BBRC), Bangalore, Karnataka for facilities rendered.

\section{References}

Cambre, R. C., D. E. Green, E. S. Smith, R. J. Montali and Bush, M. 1980. 
Salmonellosis and arizonosis in the reptile collection at the National Zoological Park. Journal of the American Veterinary Medical Association, 177(9): 800-803.

Chemical Laboratory Standards Institute (CLSI), 2006. Methods for Dilution Antimicrobial Susceptibility Tests for Bacteria that Grow Aerobically. Approved standard - seventh addition. CLSI, Wayne, Pennsylvania, USA. pp. M7-A7.

Gopee, N. V., A. A. Adesiyun and Caesar, K. 2000. A longitudinal study of Escherichia coli strains isolated from captive mammals, birds, and reptiles in Trinidad. Journal of Zoo Wildlife Medicine, 31(3): 353-360.

Janben, T., C. Schwarz, P. Preikschat, M. Voss, H. C. Philipp and Wieler, L. H. 2001. Virulence-associated genes in avian pathogenic Escherichia coli (APEC) isolated from internal organs of poultry having died from colibacillosis.
International Journal of Medical Microbiology, 291(5): 371-378.

Ley, R. E., H. Micah, C. Lozupone, P. Turnbaugh, R. R. Ramey, J. S. Bircher, M. L. Schlegel, T. A. Tucker, M. D. Schrenzel, R. Knight and Gordon, J. I. 2008. Evolution of mammals and their gut microbes. Science, 320(5883): 1647-1651.

Medici, D. D., L. Croci, E. Delibato, S. Di Pasquale, E. Filetici and Toti, L. 2003. Evaluation of DNA extraction methods for use in combination with SYBR Green I Real-Time PCR to detect Salmonella enteric serotype enteritidis in Poultry. Applied and Environmental Microbiology, 69(6): 3456-3461.

Oludairo, O. O., J. K. P. Kwaga, A. A. Dzikwi and Kabir, J. 2016. Isolation and prevalence of Escherichia coli in wild animals at the National Zoological Garden Jos, Nigeria. Bangladesh Journal of Veterinary Medicine, 14(2): 233-236.

\section{How to cite this article:}

Palanivelrajan, M., A. Sha Arun, M. G. Jayathangaraj, K. Vijayarani, Bhaskaran Ravi Latha, P. Sridevi and Porteen, K. 2018. Prevalence and Molecular Diagnosis of Escherichia coli in captive Sloth Bears (Melursus ursinus). Int.J.Curr.Microbiol.App.Sci. 7(10): 449-454. doi: https://doi.org/10.20546/ijcmas.2018.710.048 